Foss. Rec., 24, 129-133, 2021

https://doi.org/10.5194/fr-24-129-2021

(C) Author(s) 2021. This work is distributed under

the Creative Commons Attribution 4.0 License.

\title{
The polycentropodid genus Cernotina (Insecta, Trichoptera) in Miocene Dominican amber
}

\author{
Wilfried Wichard ${ }^{1}$ and Christian Neumann ${ }^{2}$ \\ ${ }^{1}$ Institute of Biology and its Didactics, University of Cologne, Herbert Lewinstraße 2, 50931 Cologne, Germany \\ ${ }^{2}$ Museum für Naturkunde, Leibniz Institute for Evolution and Biodiversity Science, \\ Invalidenstraße 43, 10115 Berlin, Germany
}

Correspondence: Christian Neumann (christian.neumann@mfn.berlin) and Wilfried Wichard (wichard@uni-koeln.de)

Received: 10 December 2020 - Revised: 11 February 2021 - Accepted: 17 February 2021 - Published: 10 May 2021

\begin{abstract}
A new polycentropodid caddisfly species is described from Miocene Dominican amber. The family Polycentropodidae is therefore represented in the Dominican amber with two species belonging to the genus Cernotina: $C$. pulchra Wichard, 2007, and C. fossilinova sp. nov. The endemic $C$. danieli Flint \& Sykora, 2004, is the only representative of the genus occurring on Hispaniola today and is similar to the two fossil species. On the Caribbean islands altogether six extant species of the genus Cernotina are registered.
\end{abstract}

\section{Introduction}

The inclusion-rich Dominican amber originated in the Miocene on the Caribbean island Hispaniola. An overview of this rich amber lagerstätte was provided by Penney (2010) and Poinar (2010). Compared to the numerous embedded plants and animals, the percentage of caddisflies found in Dominican amber is very low, less than $0.1 \%$. However, studies of amber inclusions up to 2007 have identified 31 fossil caddisfly species belonging to 15 genera in 11 families (Wichard, 2007).

The Polycentropodidae is one of the 11 families in Dominican amber but is presented by only the genus Cernotina with a single species: C. pulchra. A second Cernotina species, $C$. fossilinova sp. nov., has now been added and is described here. These two extinct species are related to the extant $C$. danieli, which is endemically distributed on Hispaniola. The low diversity of the fossil Polycentropodidae found in Dominican amber is in stark contrast to its occurrence in Eocene Baltic amber where polycentropodids are much more common and diverse (Ulmer, 1912; Wichard, 2013).

\section{Material and methods}

The sole specimen described in this study originates from Dominican amber (Dominican Republic, Hispaniola). There are three main sites in the Dominican Republic where amber is found: La Cordillera Septentrional, in the north, and Bayaguana and Sabana de la Mar, in the east. Most of the amber was deposited in turbiditic sandstones of the upper Eocene to lower Miocene Mamey group (Draper et al., 1994). Dating of Dominican amber is controversial, with the youngest proposed age of 20-15 Ma based on foraminifera (Iturralde-Vinent and MacPhee, 1996). More recently, the age of Dominican amber has been further constrained to approximately $16 \mathrm{Ma}$ (Iturralde-Vinent, 2001).

The Dominican amber with the embedded trichopteran inclusion was cut, face-grinded, and polished using a cutting machine and a polishing machine, a RotoPol-25 (Struers), with grinding paper for metallography: Grip 800, 1200, 2500 , and 4000 . Then the prepared amber piece was embedded in synthetic resin (casting resin GTS, Vosschemie, together with MEKP hardener, Vosschemie) to guarantee the protection of the holotype.

Detailed drawings and colour pictures were produced for the documentation of the amber caddisfly. The macroscope Leica M420 with apozoom 1:6 was used in combination with a Canon EOS 80D, EOS utility software, and the Zerene Stacker software. Line drawings were produced with a Leica camera lucida and digitally processed using Adobe Photoshop CS4 and Photoshop Elements 15. Measurements were made with the ocular micrometre of the macroscope.

This published work and the nomenclatural acts it contains have been registered in ZooBank on 11 December 2020 and have received the LSID number 
urn:Isid:zoobank.org:pub:ECD803D3-84F3-4143-943BA9AEB3320CEF.

\section{Systematic palaeontology}

Order Trichoptera Kirby, 1815

Suborder Annulipalpia Martynov, 1924

Family Polycentropodidae Ulmer, 1903

Genus Cernotina Ross, 1938

\section{Type species}

Cernotina calcea Ross, 1938.

Genus diagnosis (detailed in Camargos, 2020)

Ocelli absent. Maxillary palps five-segmented, first and second segments short, third segment twice as long, fourth segment about as long as third segment. The fifth segment about twice as long as third or fourth segment; this terminal segment is narrower and annulated. Labial palps threesegmented, first and second segments short, third segment clearly longer and annulated. Forewing venation with forks II, IV, and V; discoidal closed. Hind wing venation with forks II and V; discoidal cell open. Tibial spurs: 2/4/4.

\section{Cernotina fossilinova sp. nov.}

Figs. 1a-b, 2a-c

\section{Holotype}

Kept in the amber collection of the Museum für Naturkunde, Berlin (MfN: inventory number MB.I. 8613, former Wichard collection). Fossil from Miocene, embedded in Dominican amber. Body well preserved; forewing and hind wing slightly twisted, and antennae and legs present. Male genitalia visible in ventral and right lateral view.

\section{Type locality}

Dominican Republic (Hispaniola). Exact locality unknown.

\section{Type horizon}

Uncertain. Most probably early Miocene (BurdigaliumLanghium, 20-15 Ma).

\section{Etymology}

Cernotina fossilinova sp. nov. is named after the new discovery in Dominican amber.

\section{Diagnosis}

Cernotina fossilinova sp. nov. corresponds to the general characteristics of the genus and is characterized by the combination of male genital structures. The genital structures correspond to those of the endemic $C$. danieli of Hispaniola in the shape of the inferior appendage with apicodorsal blackened hook and without basodorsal lobe. The new species shows further similarities to $C$. danieli by the shape of the broad pre-anal appendage (the dorsolateral processus sensu Camargos, 2020) but is rod-shaped at the tip and not pointed. The intermediate appendages of $C$. fossilinova sp. nov. are not membranous but erect and sclerotic.

\section{Description}

Cernotina fossilinova sp. nov. corresponds in general characteristics to the genus described in the genus diagnosis.

Wings: length of forewing: $3.8 \mathrm{~mm}$. General wing venation typical of the genus (Oláh and Johanson, 2010, table 1; Camargos, 2020). However, in forewing discoidal cell probably open; crossvein m not visible. Forks II, IV, and V present, in which fork $\mathrm{V}$ short stalked; crossvein m-cul diagonal running; thyridium cell closed. Hind wing venation with forks II and V; discoidal cell open; hind wing without crossveins. The wings are uniformly fine hairy.

Male genitalia: this species bears similarities with $C$. danieli by the general shape of the inferior appendages with the blackened hook apicodorsal but without a dorsomesal row of small spinose setae. In side view the pre-anal appendage looks like a scale (dorsolateral process of the preanal appendage sensu Camargos, 2020), at the base wide and almost as long as the inferior appendage. In the middle of the rounded apical margin, a rod-shaped structure emerges mesad, which protrudes clearly above the scale and is darkly marked at apex. As far as visible as an amber inclusion, the intermediate appendage looks like a strong erect structure as long as the inferior appendage and is not membranous. The apex of the intermediate appendage is slightly capped and probably bearing very small warts.

\section{Discussion}

The genus Cernotina occurs in the Nearctic and Neotropical biogeographic regions with the greatest diversity in South America (Holzenthal and Calor, 2017); on the island Hispaniola only one endemic species is known: Cernotina danieli Flint \& Sykora, 2004. A first extinct species was found in Miocene Dominican amber: Cernotina pulchra Wichard 2007. Compared with the extant species, the inferior appendages of $C$. pulchra are similar to the shape. Its inferior appendages are lacking an apicodorsal, blackened hook. But the primary differences between the two are seen in the pre-anal appendages, which is in C. pulchra widened basally, 

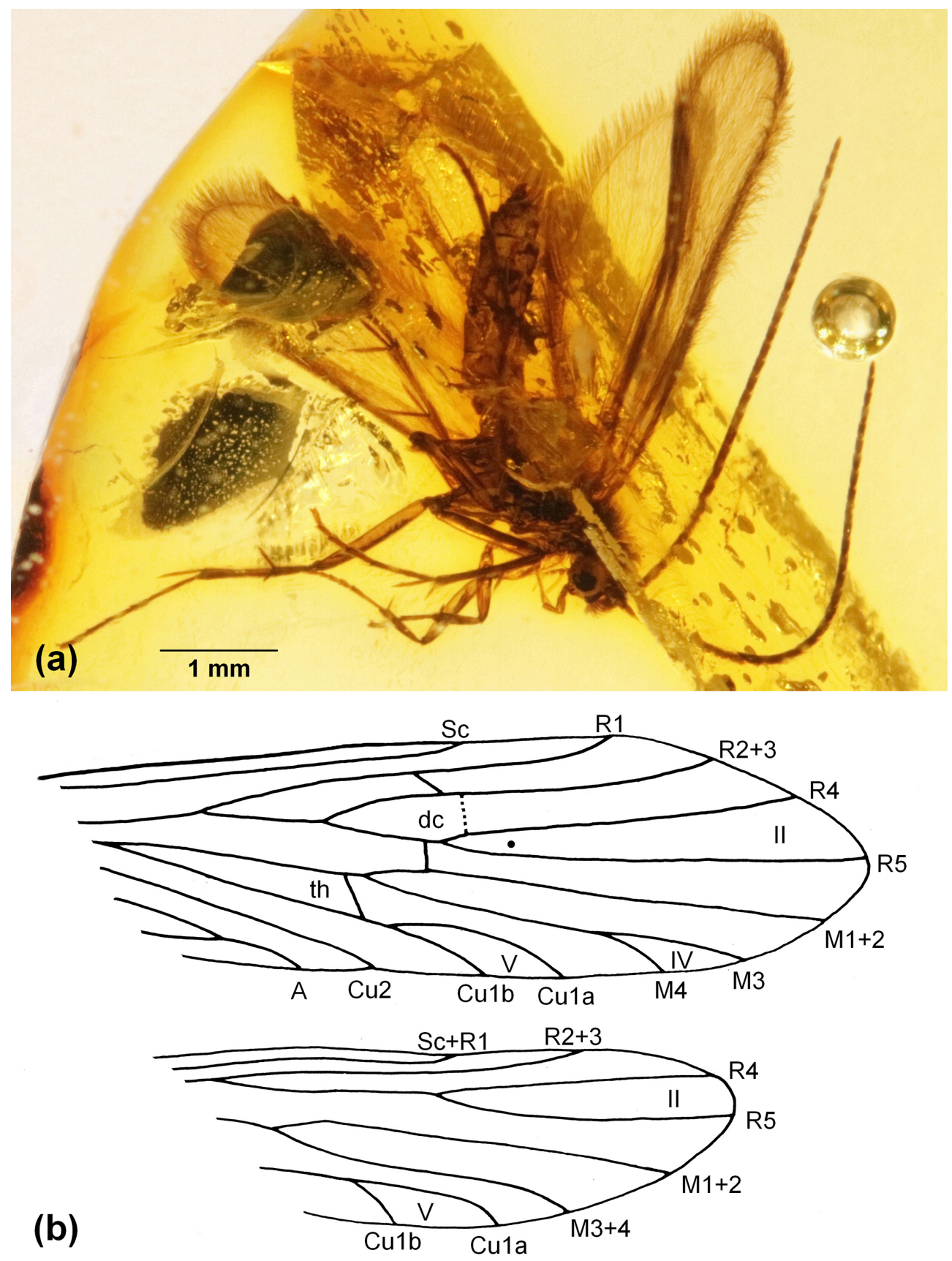

Figure 1. Cernotina fossilinova sp. nov. (a) Male in right lateral view embedded in Dominican amber. (b) Fore- and hind-wing venations: II, IV, and V denote apical forks II, IV, and V; dc denotes discoidal cell; TC denotes thyridial cell; Sc, R1, R2 + 3, R5, M1 + 2, M3, M4, Cu1a, $\mathrm{Cu} 1 \mathrm{~b}, \mathrm{Cu} 2$, and $\mathrm{A}$ denote fore- and hind-wing venations. 

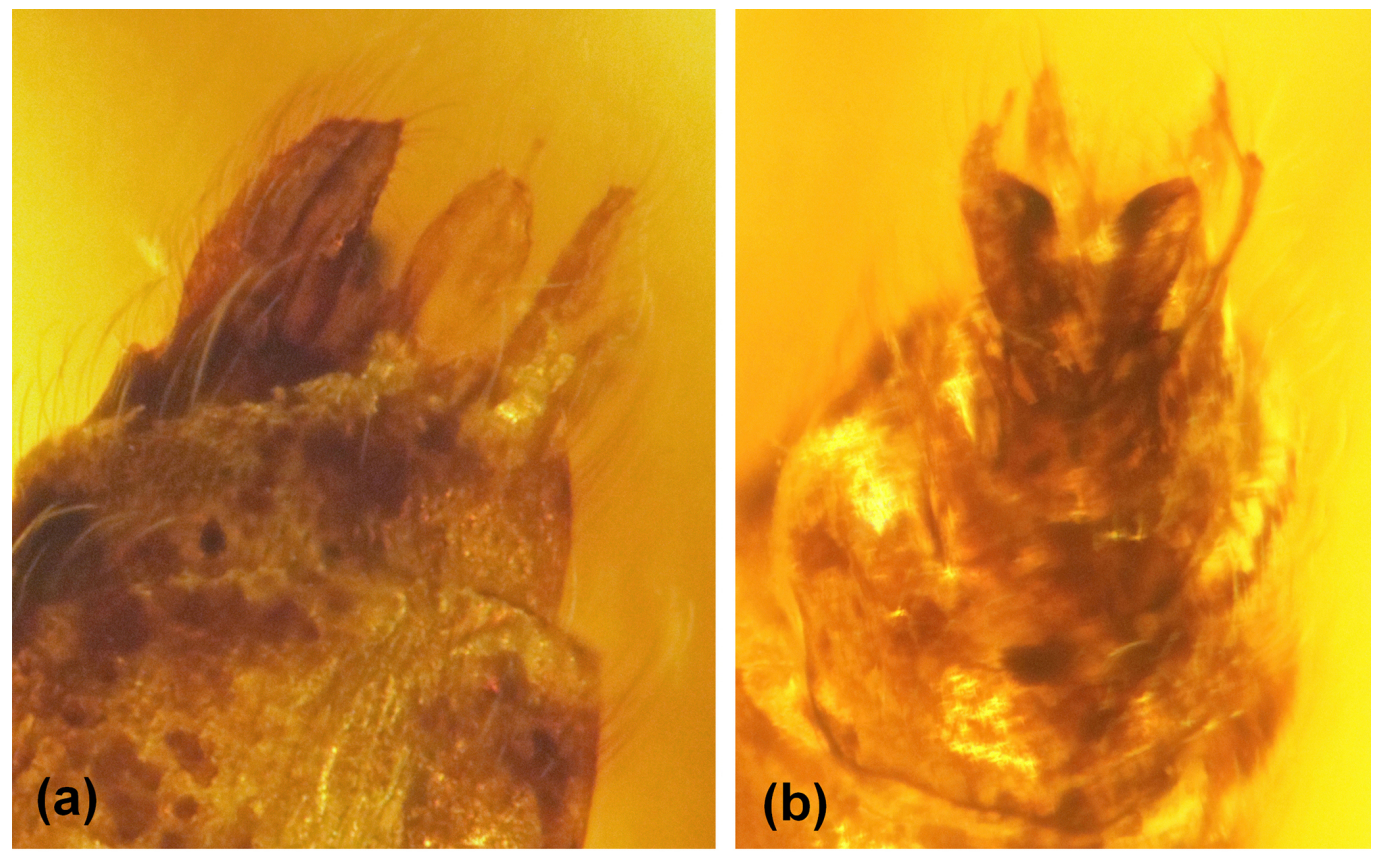

\section{intermediate appendage}

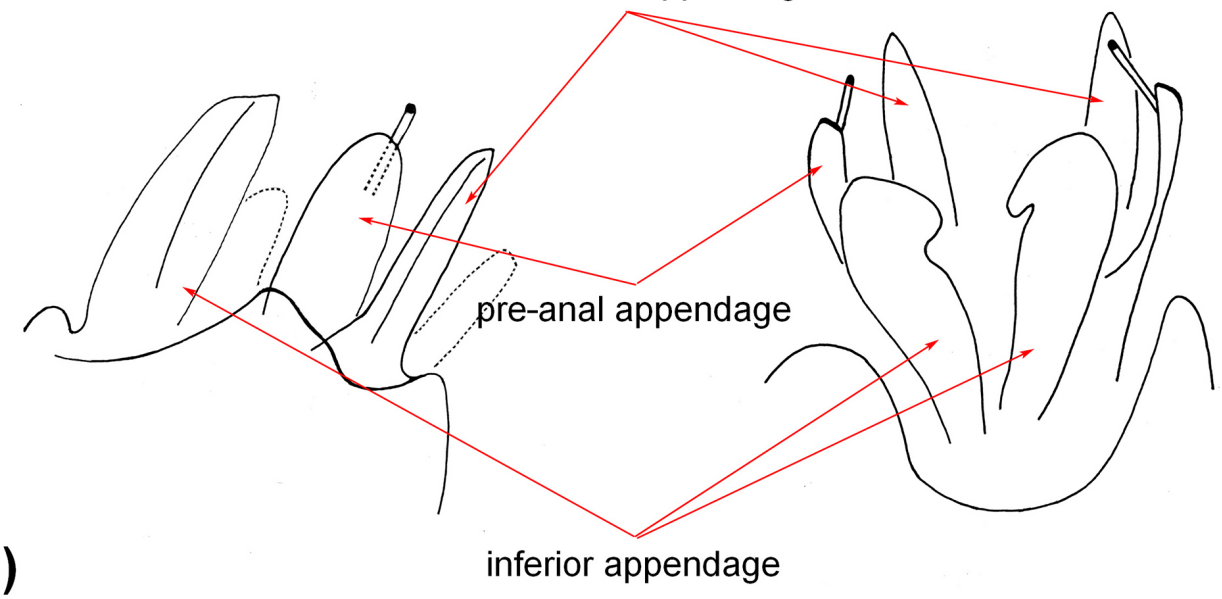

Figure 2. Cernotina fossilinova sp. nov. (a) Male genitalia in right lateral view. (b) Male genitalia in ventral view. (c) Drawing of male genitalia in lateral and ventral views.

then long and needle-like, and gradually pointed at apex and curved mesad.

The new extinct Cernotina fossilinova sp. nov. from Miocene Dominican amber is very similar to the extant $C$. danieli and more distantly to the extinct $C$. pulchra. The pre-anal appendage of $C$. fossilinova is rather scale-shaped, broad basally, and apical rounded, in the middle rising like a thin rod, and at the end slightly thickening. The inferior appendages bear a apicodorsally blackened hook, as in C. danieli, but a low dorsomesal lobe with a row of small spinose setae is not visible.

The genus Cernotina is spread with about 70 recent species from North to South America (Holzenthal and Calor,
2017; Camargos, 2020). Only a few species can be found on the Caribbean islands; Botosaneanu (2002) listed six species: C. cadeti, C. caliginosa, C. hastilis, C. lutea, C. mandeba, and C. mastelleri. Flint and Sykora (2004) completed the species list with $C$. danieli from Hispaniola, discussed above. Thus, three endemic species are known from the Greater Antilles: C. caliginosa (Jamaica), C. mastelleri (Puerto Rico), and C. danieli (Hispaniola). The two extinct Cernotina species from the Dominican amber, C. pulchra and $C$. fossilinova sp. nov., raise the question of genus colonization of the Greater Antilles, which must have taken place during the Miocene or even earlier. The geological development of the Caribbean islands is complex in detail and still 
provides an incomplete picture. However, early land bridges probably existed between North America, including Mexico, and the Greater Antilles (Ali, 2012; Burk, 1988; Coates and Obando, 1996) which allowed colonization of the islands and Hispaniola.

Data availability. The material included in this paper is deposited in the Museum für Naturkunde, Leibniz Institute for Evolution and Biodiversity Science Berlin, under the inventory number MB.I 8613 .

Author contributions. Both authors designed and performed the research and wrote the manuscript.

Competing interests. The authors declare that they have no conflict of interest.

Acknowledgements. We extend our friendly thanks to Wolfram Mey and John C. Morse who helped us improve the present contribution of the manuscript.

Review statement. This paper was edited by Carolin Haug and reviewed by Wolfram Mey and John C. Morse.

\section{References}

Ali, J. R.: Colonizing the Caribbean: is the GAARlandia landbridge hypothesis gaining a foothold?, J. Biogeogr., 39, 431-433, 2012.

Botosaneanu, L.: An annotated checklist of caddisflies from the Caribbean islands, with distribution and bibliography (Insecta, Trichoptera), B. Soc. Entomologique Fr., 107, 79-108, 2002.

Burk, K.: Tectonic evolution of the Caribbean, Annu. Rev. Earth Pl. Sci., 16, 201-230, 1988.

Camargos, L. M.: Systematics of Cernotina Ross and Cyrnellus Banks (Insecta: Trichoptera: Polycentropodidae), PhD thesis, University of Minnesota, 321 pp., 2020.

Coates, A. G. and Obando, J. A.: The geologic evolution of the Central American isthmus, in: Evolution and environment in tropical America, edited by: Jackson, J. B. C., Budd, A. F., and Coates, A. G., 21-56, University of Chicago Press, Chicago, 1996.
Draper, G., Mann, P., and Lewis, J. F.: Hispaniola, in: Caribbean geology: an introduction, edited by: Donovan, S. and Jackson, T. A., 129-150, The University of the West Indies Publishers' Association, Kingston, Jamaica, 1994.

Flint, O. S. and Sykora, J. L.: Caddisflies of Hispaniola, with special reference to the Dominican Republic (Insecta: Trichoptera), Ann. Carnegie Mus., 73, 1-60, 2004.

Holzenthal, R. W. and Calor, A. R.: Catalogue of the Neotropical Trichoptera (Caddisflies), ZooKeys, 654, 1-566, 2017.

Iturralde-Vinent, M. A.: Geology of the amber-bearing deposits of the Greater Antilles, Caribb. J. Sci., 37, 141-167, 2001.

Iturralde-Vinent, M. A. and MacPhee, R. D. E.: Age and paleogeographical origin of Dominican amber, Science, 273, 1850-1852, 1996.

Kirby, W.: Strepsiptera, a new order of insects proposed, and the characters of the order, with those of its genera, Transactions of the Linnean Society of London Zoology, 11, 86-122, 1815.

Martynov, A. V.: Rucheiniki (caddisflies), Prakticheskaya Entomologiya, 5, 1-384, 1924 (in Russian).

Oláh, J., and Johanson, K. A.: Generic review of Polycentropodidae with description of 32 new species and 19 new species records from the Oriental, Australian and Afrotropical Biogeographical Regions, Zootaxa, 2435, 1-63, 2010.

Penney, D.: Dominican Amber, in: Biodiversity of fossils in amber from the major world deposits, edited by: Penney, D., 22-41, Siri Scientific Press, Manchester, 2010.

Poinar, G.: Palaeoecological perspectives in Dominican amber, Ann. Soc. Entomologique Fr., 46, 23-52, 2010, https://doi.org/10.1080/00379271.2010.10697637

Ross, H. H.: Descriptions of Nearctic caddis flies (Trichoptera) with special reference to the Illinois species, Bulletin of the Illinois Natural History Survey, 21, 101-183, 1938.

Ulmer, G.: Über die Metamorphose der Trichopteren, Abhandlung Naturw. Verein Hamburg, 18, 1-154, 1903 (in German).

Ulmer, G.: Trichopteren des Baltischen Bernsteins, Beiträge zur Naturkunde Preußens, 10, 1-380, 1912 (in German).

Wichard, W.: Overview and descriptions of caddisflies (Insecta, Trichoptera) in Dominican amber (Miocene), Stuttgarter Beiträge zur Naturkunde Serie B (Geologie und Paläontologie), 366, 1$51,2007$.

Wichard, W.: Overview and descriptions of Trichoptera in Baltic Amber: Spicipalpia and Integripalpia, Museum für Naturkunde, Berlin, Kessel, Remagen, Germany, 230 pp., 2013. 